NBER WORKING PAPER SERIES

\title{
JOB HOPPING IN SILICONE VALLEY: SOME EVIDENCE CONCERNING THE MICRO-FOUNDATIONS \\ OF A HIGH TECHNOLOGY CLUSTER
}

\author{
Bruce Fallick \\ Charles A. Fleischmann \\ James B. Rebitzer \\ Working Paper 11710 \\ http://www.nber.org/papers/w11710 \\ NATIONAL BUREAU OF ECONOMIC RESEARCH \\ 1050 Massachusetts Avenue \\ Cambridge, MA 02138 \\ October 2005
}

The views expressed in this paper are those of the authors and do not necessarily represent the views or policies of the Board of Governors of the Federal Reserve System or its staff. We would like to thank our editor, Daron Acemoglu, and two anonymous referees for their insights. In addition we received help and comments from the following people: Carliss Baldwin, Peter Cappelli, Sue Helper, David Levine, Mari Rege, Annalee Saxenien. Lowell Taylor, Rob Valletta, participants at seminars at Case Western Reserve University and the National Bureau of Economic Research, staff at the Bureau of Labor Statistics and Siddhartha Chowdri, Paul Adler, Maura McCarthy, and Jennifer Gregory for research assistance. The usual caveat applies. The views expressed herein are those of the author(s) and do not necessarily reflect the views of the National Bureau of Economic Research.

(C2005 by Bruce Fallick, Charles A. Fleischmann, and James B. Rebitzer. All rights reserved. Short sections of text, not to exceed two paragraphs, may be quoted without explicit permission provided that full credit, including () notice, is given to the source. 
Job Hopping in Silicone Valley: Some Evidence Concerning the Micro-Foundations of a High Technology Cluster

Bruce Fallick, Charles A. Fleischmann, and James B. Rebitzer

NBER Working Paper No. 11710

October 2005

JEL No. R12, L63, O3, J63, J48

\begin{abstract}
In Silicon Valley's computer cluster, skilled employees are reported to move rapidly between competing firms. This job-hopping facilitates the reallocation of resources towards firms with superior innovations, but it also creates human capital externalities that reduce incentives to invest in new knowledge. Using a formal model of innovation we identify conditions where the innovation benefits of job-hopping exceed the costs from reduced incentives to invest in human capital. These conditions likely hold for computers, but not in most other settings. Features of state law also favor high rates of inter-firm mobility in California. Outside of California, employers can use non-compete agreements to inhibit mobility, but these agreements are unenforceable in California.
\end{abstract}

Using new data on labor mobility we find higher rates of job-hopping for college-educated men in Silicon Valley's computer industry than in computer clusters located out of the state. Mobility rates in other California computer clusters are similar to Silicon Valley's, suggesting some role for state laws restricting non-compete agreements. Consistent with our model of innovation, we also find that outside of the computer industry, California's mobility rates are no higher than elsewhere.

Bruce Fallick

Federal Reserve Board

bruce.fallick@frb.gov

Charles A. Fleishcmann

Federal Reserve Board

charles.a.fleischmann@frb.gov

James B. Rebitzer

Case Western Reserve University

Weatherhead School of Management

11119 Bellflower Rd

Cleveland, $\mathrm{OH}$ 44106-7235 


\section{Introduction}

The geographic clustering of firms is a ubiquitous, but poorly understood, feature of advanced economies. ${ }^{1}$ Explanations for geographic concentration have focused on "external economies of scale" or equivalently "agglomeration economies". These terms refer to mechanisms that improve the efficiency of production when other related firms co-locate in an area. In this paper we use new data to examine a much-discussed source of "external economies of scale" in a much-discussed industry and economic cluster. Our focus is on the computer industry and the agglomeration economy we investigate is the easy mobility of skilled employees among firms in Silicon Valley.

Annalee Saxenian (1994) was among the first to observe that high rates of mobility were a source of agglomeration economies in Silicon Valley. ${ }^{2}$ She argued that the sustained highrates of innovation of computer firms were the result of two unique aspects of the industrial organization of the region. The first feature was that computer systems manufacturers relied on networks of independent suppliers who specialized in incorporating the latest technological advances into modular components (Saxenian 2000). The modular nature of these components increased the rate of technical innovation in the region by enabling rival suppliers to pursue simultaneous and independent innovation strategies so long as the resulting components conformed to the design rules that integrated the components into the final product (Baldwin and Clark, 1997).

The second key feature of the industrial organization of Silicon Valley was the rapid

1 For an excellent and comprehensive review of the literature on geographic clustering see Rosenthal and Strange (2003). Porter (1998) discusses the policy implications of clusters.

2 Some discussion of mobility preceded Saxenian's work; see for example, Angel 1989. 
movement of technically sophisticated employees between firms in the region. This high rate of mobility among technical employees reinforced the benefits of modularity because skilled employees rapidly transferred from firms with inferior designs to those with superior designs.

Job-hopping between companies, however, also increases the likelihood that knowledge acquired in one firm is employed in another. These knowledge spillovers can hamper innovation by reducing the rewards to investing in human capital. An implicit assumption in Saxenian's discussion of Silicon Valley is that the benefits of the agglomeration economies exceed the attendant losses due to knowledge spillovers. Gilson (1999) brought attention to this assumption and observed that high rates of mobility by knowledgeable employees were likely to impose nontrivial costs on employers. These costs may cause employers to take actions to limit job-hopping even when the social benefits of agglomeration economies exceed the costs. "Non-compete agreements", according to Gilson, are the most important legal mechanism for reducing interfirm mobility. These agreements limit an employee's ability to work with competing firms in a specific geographic area and for a specific period of time. It turns out that features of California state law introduced serendipitously in the 1870's make it impossible for employers to enforce non-compete agreements. But for this historical accident, Silicon Valley employers would have had at their disposal an easy way to inhibit costly mobility. California's legal system is exceptional in its treatment of non-compete agreements. Thus Gilson's hypothesis may explain why mobility (and agglomeration economies) should be unusually high in Silicon Valley. His hypothesis also suggests that similar high rates of mobility should be observed in computer clusters elsewhere in California, but not in other states.

Saxenian's and Gilson's accounts have captured much attention in management and policy circles. Unfortunately data limitations have, until now, precluded direct empirical 
examination of some of the key features of the story - especially the movement of employees between firms within a narrow geographic region and industry. ${ }^{3}$

In this paper we exploit little-used data from the Current Population Survey to measure the rate of employer-to-employer mobility in Silicon Valley and elsewhere. We find, first, that employees working in the computer industry cluster in Silicon Valley do indeed have higher rates of mobility than similar computer industry employees in other metropolitan areas having large information technology clusters. Second, and consistent with Gilson's hypothesis that California state law is important for sustaining hyper-mobile employment, there appears to be a "California" effect on mobility. That is we find similar high rates of mobility of computer industry employees throughout the state of California. Third, we find that the mobility patterns observed for employees working in the computer industry do not hold for employees in other industries residing in these same locations. This last result suggests that interaction between features of the computer industry and those of a particular geographic location, rather than features of the location alone, drive our findings.

The approach we take differs in two ways from other empirical studies of agglomeration economies and human capital externalities. ${ }^{4}$ First, we focus on employee mobility within a labor

3 The only other paper we know of that examines mobility in high technology clusters is Almeida and Kogut (1999). They use patent records to study the mobility patterns of 438 individuals who held major, semiconductor-related patents. They find higher rates of mobility in Northern California than elsewhere in the country.

4 Acemoglu and Angrist (2000) and Moretti (2004) study how returns to education vary with the educational attainment of others in a geographically specified labor market (defined respectively as cities or states). Moretti finds some evidence in favor of the existence of human capital externalities while Acemoglu and Angrist's results offer less support. Moretti suggests that these differences result from the use of different instrumenting strategies that give weight to different parts of the labor market (Moretti, 2004, p. 207). In a second paper, Moretti (2004b) reports that the productivity of plants in cities that experience large increases in the share of college graduates rises more than the productivity of similar plants in cities that experience small increases in the share of college educated. This remarkable study offers strong support for the existence of 
market rather than on the returns to education. We adopt this approach because inter firm mobility is more closely related to the agglomeration economy conjectured to operate in Silicon Valley. ${ }^{5}$ Secondly, we examine our variable of interest for a specific industry within geographically specified labor markets. This industry focus is important because the agglomeration economies we analyze are likely to be especially important in industries like computers where the gains from innovation are large but also uncertain.

Our paper proceeds in three parts. In the next section, we consider the effect of jobhopping on human capital investments and agglomeration economies and identify the conditions necessary for a Silicon Valley type computer cluster to appear. In section three, we present our empirical results. The paper concludes with a discussion of the limitations of our analysis and issues for further study.

\section{Human Capital Externalities, Agglomeration Economies, and Non Compete Agreements}

In this section we consider the effect of job-hopping within an industrial cluster on human capital investments and agglomeration economies. We seek to establish three points. First, that rapid employee mobility within a cluster will lead to underinvestment in human capital. Secondly, that job hopping can be a source of agglomeration economies, so long as the underinvestment in human capital is not "too large". Third, that conditions prevailing in the computer industry make it especially likely that hyper-mobility will produce agglomeration economies.

Investments in Human Capital and Human Capital Externalities: Our analysis relies

agglomeration economies linked to human capital, but does not assess the mechanisms by which these spatial agglomerations work. In contrast, our work focuses on the very specific agglomeration mechanism proposed for computer clusters - job mobility in the context of the modular innovation process in computers.

5 Indeed the model of agglomeration economies and human capital externalities we rely on does not make clear predictions about wages (see Acemoglu 1997, p. 453). 
heavily on the model in Acemoglu (1997). ${ }^{6}$ Following Acemoglu (1997) we posit an imperfect labor market in which employers and employees bargain over the surplus produced in period two of the employment relationship after investments in human capital are made in period one. ${ }^{7}$ The value produced in period two is $y+a t$, where $y$ is a positive constant, $a$ is the quality of the firm's technology, and $t$ is the level of general human capital investments made in period one. ${ }^{8}$ An important feature of this specification is that technology and human capital investments are complementary, the returns to human capital investment increase the higher the quality of technology.

Into this setting we introduce job separation of the sort analyzed in Acemoglu (1997). Specifically we assume that employment relationships are severed by random shocks that occur with probability $s$ after human capital investments are made in period one. In the reallocation of labor subsequent to these shocks, the dislocated employees each find work at a different firm in period two. Similarly the employers affected by these shocks will also have new employees in period two. The surplus produced by the period two employer's technology and the period two employee's human capital is divided according to an exogenously determined sharing rule. Thus

6 Acemoglu's model establishes a number of important results regarding knowledge spillovers. $\mathrm{He}$ finds, for example, that investments in general skills will be suboptimal and that part of the costs might be borne by employers (Acemoglu, 1997). A related paper (Acemoglu 1996) offers a new microeconomic explanation for increasing returns to human capital accumulation.

7 In Acemoglu (1997), the key labor market imperfection is costly job switching. Search costs create a job-specific employment rent over which workers and employers bargain. This assumption of high job switching costs may not be appropriate, however in a setting characterized by hyper-mobile employees. Instead we motivate the bargaining over employment rents by positing asymmetric information between the current employer and other firms in the cluster. Acemoglu and Pischke (1999) discuss a number of ways that imperfect information about the nature of human capital investments or about the ability of employees can produce employment rents. They also demonstrate that in such settings it may be efficient for employers as well as employees to invest in general human capital.

8 The economy is composed of an exogenously determined number of firms each with a Leontieff production function in which one, risk-neutral employee produces a fixed output in period two based upon technology and investments in human capital made in period one. 
employers with new employees in period two benefit from human capital investments made in a different employment relationship in period one. The resulting externality reduces incentives to invest in human capital.

More formally, Acemoglu (1997 p. 451, equation 2) writes the ex ante total surplus produced by each employment relationship as:

$$
\text { (1) } T S=\frac{(1-s)(y+a t)+s[\beta(y+a t)+(1-\beta)(y+a E(\tilde{t}))]}{1+r}-c(t)
$$

The cost of acquiring knowledge, $\mathrm{c}(t)$, is a convex function of $t$, the amount of general human capital acquired. These costs are incurred in period one while the benefits from the human capital investments arrive in period two (hence the discounting). Each employment relationship stays intact with probability $(1-s)$ and produces $y+a t$. Employment relationships sever with probability $s$. In this case, the employee gains a proportion, $0<\beta<1$, of the surplus produced in the second period using the employer's technology and their own human capital. Conversely, employers gain a fraction, $(1-\beta)$, of the surplus produced by their own technology and the human capital of their new employee. The expected human capital of the employees displaced by the random shock is represented by $E(\tilde{t})$.

Acemoglu (1997, proposition 2 p. 451) demonstrates that in this setting there is a unique equilibrium in which training investments maximize the total surplus as described in (1) above. If we simplify equation (1) by specifying that the cost of investment function $c(t)=c t^{2}$, then we can use this result to derive an explicit expression for investments in human capital:

$$
\text { (2) } \hat{t}=\frac{a[(1-s)+s \beta]}{2 c}
$$

In this case it is also easy to show that if parameters $s$ and $\beta$ are such that $0<s, \beta<1$ then surplus will be maximized only when both employers and employees pay for some investments 
in $t$. Notice that with these parameter values $d \hat{t} / d \beta>0$ and $d \hat{t} / d s<0$. These results are

intuitive. Incentives to invest in human capital increase with $\beta$ because employees dislocated in period two recoup a greater return on prior investment in human capital. Conversely, incentives to invest in human capital are reduced when the probability of separation increases because with each separation some fraction of the benefits from period one human capital investments spill over to other employers.

Using equation (2) the value produced by each employment relationship in period two is:

$$
y+a \hat{t}=y+\frac{a^{2}[(1-s)+s \beta]}{2 c}
$$

\section{Introducing Silicon Valley Type Agglomeration Economies: ${ }^{9}$ According to Saxenian}

(1994) and Baldwin and Clark (2000), the technological dynamism in computers stems in part from their modular design. Modularity enables rival suppliers to pursue simultaneous and independent innovation strategies so long as the resulting components conform to the design rules that integrate components into the final product. Computer makers can then pick the best of these for use in their products.

A simple way to introduce modularity into Acemoglu's set-up is to allow it to shape the technology variable, $a$, in equation (3). More specifically we assume that innovation is a random process and the quality of the technology that emerges, $a$, is determined by a random variable drawn from a uniform distribution ranging from 0 to $\gamma$. The larger is $\gamma$, the greater is the

Our discussion focuses on the sorts of agglomeration economies highlighted by observers of the computer industry. There are, of course, many other potential sources of agglomeration economies. Rotemberg and Saloner (2000) consider the role that clusters play in inducing industry-specific human capital investments. They argue that suppliers will be reluctant to undertake industry-specific investments if they anticipate only one local customer for their product. The fear that a single customer may exert monopsony power is reduced, however, if a number of customers locate in an area. The result, in our context, is a computer cluster with many computer makers and many component suppliers. 
expected return to innovative activity and the greater is the variation in outcomes. If there are $g$ component makers in the industrial cluster, the expected value of the "best" design to emerge from the component makers is the first order statistic for the uniform distribution ranging 0 to $\gamma$ :

$$
\text { (4) } \quad a=\frac{g \gamma}{g+1} \text { with } g \geq 1
$$

It is clear from (4) that the value of the best technology increases with the number of component suppliers in the cluster, $g$, although there are diminishing marginal returns to $g$. Note as well that $a$ is also increasing in $\gamma$.

For the innovation process described in (4) to be a source of agglomerateion economies, it needs somehow to be localized (Rotemberg and Saloner 2000). This is where job-hopping enters the picture. The firm with the "best" component design can sell its product to all the computer makers in the district, provided it hires enough of the employees working at other component makers to achieve the requisite scale of production. Since employees change jobs most easily when they do not have to move their households, the innovation advantages of modularity and job-hopping are best realized when the $g$ component makers locate in a particular location. ${ }^{10}$

This argument is not sufficient, however, to establish that job-hopping is a source of agglomeration economies. The random process by which firms discover key innovations and the subsequent reallocation of labor to those firms produces exactly the sort of random shocks that with significant tacit knowledge interact with one another and these interactions facilitate informal yet value creating information exchanges between computer makers and component suppliers. These informal exchanges are hard to document, but a number of authors have used patent citations as a proxy and they find that citations are geographically localized (see Agrawal, Cockburn and McHale, 2003, for a review and some new evidence.) Including informal information exchanges in our model would enrich the analysis, but would not alter the key results. 
occupy center stage in Acemoglu's analysis. We know from (3) that increasing $s$, the probability that employment relationships are disrupted, has ceteris paribus, the effect of reducing incentives to invest in human capital. Thus for job-hopping to be a source of agglomeration economies, we need to establish the conditions under which increasing the value of the technology, $a$, offsets the potential losses due to reduced incentives to invest in general human capital, $t$.

Our approach to this problem is to make the separation rate, $s$, an endogenous result of the competition between the $g$ component makers in the cluster. We do this in the simplest possible way by assuming that the firm with the "best" component design can sell its product to all the computer makers in the district, provided it hires the $g$-1 employees working at other suppliers to achieve the requisite scale of production in period two. ${ }^{11}$ Since all firms are ex-ante equally likely to discover the "best" design and since there can only be one "best" design, the probability that any component supplier finds it is $1 / g$. Thus, $s=1-(1 / \mathrm{g})$. Substituting equation (4) and this expression for $s$ into equation (3), we get:

$$
y+\hat{a} t=y+\frac{\gamma g}{2 c(1+r)(g+1)}\left(\frac{1}{(g+1)}+\beta \frac{(g-1)}{(g+1)}\right) \text { for } g \geq 1
$$

Taking the derivative of $y+\hat{a} t$ with respect to $g$ we find

$$
\frac{d(y+\hat{a} t)}{d g}=\frac{\gamma}{2 c(1+r)} \frac{\beta(3 g-1)-(g-1)}{(g+1)^{3}}>0 \text { if and only if } \beta>\frac{g-1}{3 g-1}
$$

By definition, agglomeration economies exist when $d(y+\hat{\alpha} t) / d g>0$. The derivative includes the opposing influence of agglomeration economies and human capital externalities. So long as the externalities do not reduce incentives to invest in knowledge too badly, i.e. so long as $\beta$ is above some threshold, the gains from allocating employees to firms with the best technology working at the "winning" component maker can supply enough components to meet demand. 
ex-post exceed the losses due to reduced human capital investments ex-ante. ${ }^{12}$ Because the marginal benefit to innovation of adding more component suppliers to the cluster declines in $g$, the minimum threshold value of $\beta$ increases with $g$. The results in (6) also demonstrate that the gains from agglomeration economies are greatest when $\gamma$ is large. This follows because the advantages of having multiple independent and simultaneous experiments are greatest when the gains to innovation are both large and uncertain. Close observers of the innovation process in computers agree that $\gamma$ is especially large in this industry (Baldwin and Clark, 1994 and 2000; and Aoki, 2001). ${ }^{13}$

Non-Compete Agreements: Covenants not to compete are a legal mechanism to reduce the costly human capital externalities that result from job-hopping. ${ }^{14}$ To the extent that noncompete agreements reduce the probability that an employee will be working for a new employer in the future, these covenants can induce higher levels of human capital investment, $t$. Firms may find it individually desirable to exercise these agreements even if this reduces the technological vitality of the industrial cluster. And if such covenants are a more cost-effective way of inhibiting mobility than other methods (such as deferred compensation schemes), then we should expect to see lower mobility in clusters where non-compete agreements are available.

The number of component makers does not, of course, grow without limit. For any given level of $\beta$ it is straight-forward to derive the equilibrium value of $g$, i.e. the value of $g$ where the return to a firm entering the cluster just equals the return to setting up operations outside the cluster. "For an industry like computers, in which technological uncertainty is high and the best way to proceed is often unknown, the more experiments and the more flexibility each designer has to develop and test the experimental modules, the faster the industry is able to arrive at improved versions" (Baldwin and Clark, 1994, p. 85). Gilson's original discussion of non-compete agreements in high technology districts emphasized their importance for firms seeking to retain control over trade secrets and proprietary innovations should employees move to competitors. Acemoglu's (1997) analysis makes clear, however, that the costs of knowledge spillovers can be substantial even when all human capital is general and when firms retain full control over their trade secrets and technology. As a contractual form, noncompete agreements are well suited to inhibiting both these sorts of knowledge spillovers because the (unknown) future employer needn't be party to the initial agreement. 


\section{Empirical Results}

In this section we marshal little-used data on employee mobility to answer three questions that follow directly from the preceding analysis. First, is the inter-firm mobility of employees in the computer industry indeed higher in Silicon Valley than in other IT clusters in states with enforceable non compete agreements? Second, is there a "California" effect on the rate of inter-firm mobility for computer industry employees, as one might expect if the agglomeration economies are due to features of California state law? Third, since the conjectured agglomeration economies in Silicon Valley are manifest most strongly under special circumstances (i.e. when $\gamma$ is large), do the mobility patterns we observe in the computer industry hold for employees in the same location who are not employed in the computer industry? The discussion in the preceding section suggests that the answers to these questions ought to be yes, yes and no.

Data:

The data we use in our analysis come from a relatively new feature of the Current Population Survey (CPS). With the redesign of the CPS in January 1994, the Census Bureau sought to reduce the number of questions asked afresh to respondents each month. To avoid unnecessary duplication, interviewers asked some questions that refer back to the answers given in the previous month. One specific instance of this "dependent interviewing" approach allowed for the collection of the mobility data we use in this study. If a respondent is reported employed in one month and was also reported employed in the previous month's survey, the interviewer asks the respondent whether they currently work for the same employer as reported in the previous month (the interviewer reads out the employer's name from the previous month to ensure accuracy). If the answer is yes, then the interviewer carries forward the industry data from 
the previous month's survey. If the answer is no, then the respondent is asked the full series of industry, class, and occupation questions. Using the answer to this routing question, we can identify stayers (workers employed in two consecutive months at the same employer) and movers (workers who changed employers between two consecutive months).

The CPS data on month-to-month mobility are well suited for studying agglomeration economies. The size and scope of the CPS sample is far greater than in most other householdbased survey data and this allows for quite detailed analysis by geographic location, educational level, and industry. In addition, the CPS survey is administered monthly and this should reduce the recall errors found in other household surveys that ask respondents to remember their employers over longer stretches of time. Finally, we can link the employment transition data to demographic and employment data for each individual. This allows us to consider the importance of potentially confounding influences on employer-to-employer mobility. (See Fallick and Fleischman 2004 for a fuller description of the data.)

The computer industry agglomeration economies that motivate our study emphasize the mobility of highly educated employees. For this reason, we restrict our sample to those having a minimum of four years of college who also live in metropolitan areas having information technology clusters. ${ }^{15}$ In addition, we focus our analysis on men to eliminate the potentially confounding effect of gender on mobility. Finally, we pool across all the years in our sample period (1994 - 2001), in order to achieve a sample in the computer industry large enough for

Information on metropolitan areas with the top 20 IT clusters by employment in the year 2000 is taken from The Cluster Mapping Project (2003). We include the following metropolitan areas (MSAs): San Jose; Boston (with Worcester Lawrence MA_NH); Austin; Dallas; Seattle; Phoenix; Orange County; Washington; Portland; San Francisco; Raleigh; Chicago; Los Angeles; San Diego; Minneapolis; Oakland; Atlanta; Philadelphia; Houston; and Denver. Details on the identification of clusters are in Porter (2003). We define Silicon Valley as being in the MSAs of San Jose, San Francisco and Oakland, but our results also hold if we define Silicon Valley as San Jose only. 
analysis. All of our results include fixed year and month-of-interview effects to net out the influence of year-to-year as well as seasonal variation in economic activity. The resulting sample has 44,202 individuals and 156,149 month-to-month observations. The number of month-to-month observations for each individual ranges from 1 to 6 with the median being $3 .^{16}$ Of the individuals in our sample, 3,768 (or $7.84 \%$ ) were observed to have changed employers at least once. The monthly rate of employer-to-employer job change is 2.41 percent. $^{17}$

Results:

Our empirical investigation requires that we identify employees in the computer industry.

If we define this industry too broadly, we risk including in our sample employees who are not part of the computer cluster. Alternatively a very narrow definition risks excluding some employees who ought to be counted as part of the cluster. For this reason, we present our key

The CPS has a short panel structure - respondents are in the sample for four consecutive months, out for 8 consecutive months and in again for four consecutive months. Thus each individual can have at most 6 month-to-month potential transitions. The median is less than 6 for the following reasons: (1) some individuals' final four months occurred in 1994; (2) some individuals' initial four months occurred in 2001; and (3) for administrative reasons only 6 months of data are available for 1995. In addition, some individuals move from one month to the next and these are lost to the survey because an individual is identified, in part, by the location of their residence. Others are lost to nonresponse or other data problems. After taking account of these factors, the number of individuals lost from the sample is consistent with other published studies. Details on the algorithm used to match individuals from one month to the next are available in Fallick and Fleishman (2004).

17 If we assume that this rate of mobility holds for every month an individual is on a job, then the probability a newly hired employee will be at the job in one year is $(1-.0241)^{11}=0.76$. This figure may appear high, but it is worth noting that the hazard of exiting a firm is not constant. Our confidence in the CPS mobility data is further strengthened by the fact that it produces estimates for broader measures of turnover that match well with data from the Longitudinal EmployerHousehold Dynamics (LEHD) program at the Census Bureau. The LEHD uses tax records from the unemployment insurance program that constitute a near universe-count of on-the-books wage and salary employment in the participating states. The LEHD matches these records over time by employer and employee. We tabulated data from 20 of the 50 states, representing about 55 percent of total employment in the U.S., for a period from late-1995 through mid-2003. (The data are available, state by state, at "http://lehd.dsd.census.gov".) Over this period, the average quarterly separation rate and accession rate from the LEHD, as a percent of employment, were $20.1 \%$ and $20.6 \%$, respectively. The comparable rates from our matched CPS data are $19.9 \%$ and $19.7 \%$, respectively. 
results in Tables 1 and 2 using both a broad and narrow definition of the industry.

Table 1 estimates rely on a broad definition of the industry. In it we present probit estimates of the probability that an individual in SIC 35 and 36 in month $t$ changes employers before being re-interviewed in month $t+1 .{ }^{18}$ The estimates in columns 1 and 2 are for a sample of 2972 men having 8966 month-to-month observations. The mean of the dependent variable is 0.0195 suggesting that employers were observed to change employers in 1.95 percent of the potential transitions. For continuous variables, the probit estimates are presented as derivatives evaluated at the mean of the right-hand side variables; for dummy variables the estimates are presented as the difference in probabilities as the value of the variable switches from 0 to 1 with all other right-hand side variables at their means. Thus the 0.008 coefficient on the variable Silicon Valley in column 1 indicates that living in Silicon Valley increases the rate of employer to employer job change by 0.8 percentage point. This effect is both statistically and behaviorally significant -- suggesting employer-to-employer mobility rates are more than $40 \%$ higher than the sample average. On this basis, the impression of hyper-mobility that Saxenian noted in studies of the late 80s and early 90s appears to have persisted in Silicon Valley throughout the 1990s.

Column 2 of Table 1 introduces a new variable, California, which is a dummy variable equal to 1 if an employee in the computer industry in time $t$ resides in a metropolitan area with an IT cluster in the state of California. In this specification, we observe that the coefficient on Silicon Valley falls to zero while the coefficient on California is both behaviorally and statistically significant. Ceteris paribus, employees in California's IT industries have a rate of employer-to-employer mobility that is 1.1 percentage points above the sample mean (z score Industrial and Commercial Machinery and Computer Equipment; and Electronic and Other Electrical Equipment and Components, Except Computer Equipment. 
2.66) - an increase of 56 percent. These results are consistent with Gilson's hypothesis regarding California law. The Silicon Valley effect on mobility appears to run throughout the state's computer clusters.

Column 3 of Table 1 estimates job change rates separately for each of the MSAs in California having IT clusters. Employees in the computer industry residing in Los Angeles and San Diego had mobility rates virtually identical to Silicon Valley. The coefficient on Los Angeles is statistically significant at the 5\% level and San Diego is significant at the 10 percent level. This reinforces the conclusions drawn from column 2, i.e. that the high Silicon Valley mobility rates can be found elsewhere in California.

The mobility measures used in columns (1) through (3) look at all job changes for employees in the computer industry in month $t$ regardless of the industry to which they move. In contrast, the estimates in columns (4) through (6) count as moves only those job changes in which the employer in month $t$ and in month $t+1$ are in the computer industry. The mean of this new intra-industry measure of job change is 0.009 , indicating that roughly $46 \%$ of the employer to employer job changes for employees in the computer industry are to other employers in the same two SIC industries.

The results in column (4) confirm the presence of high rates of employer-to-employer mobility in Silicon Valley. The coefficient on Silicon Valley is 0.008 (z score $=3.27$ ), suggesting that this measure of job change is nearly $90 \%$ higher in Silicon Valley than the sample mean. Column (5) introduces the California dummy. The coefficient on this variable is positive, but small in magnitude (0.002) and imprecisely measured $(\mathrm{z}=0.880)$. As importantly, the coefficient on Silicon Valley falls by twenty-five percent and also becomes statistically insignificant at conventional levels. One can, however, easily reject the hypothesis that Silicon 
Valley and California are jointly insignificant $\left(\chi^{2}(2)=11.28\right.$ and Prob $\left.>\chi^{2}=0.0035\right)$. Taken together, these results suggest that given the smaller number of employer-to-employer moves within the computer industry (as we define it), it is difficult to reliably distinguish a San Jose effect from a California effect.

In column (6) we disaggregate the California effect by looking at individual MSAs. We observe a large and positive coefficient on Silicon Valley (0.009 and significant at the $1 \%$ level). In contrast the coefficients on the other California MSA's are essentially zero and very imprecisely measured.

Taken together, the results in column (6) support Saxenian's claim that intra-industry mobility is higher in Silicon Valley than in computer industries located elsewhere. These results do not offer support for Gilson's hypothesis -- heightened mobility seems to be concentrated in Silicon Valley, but is not observed in other MSAs.

Why do we observe a California effect on mobility in columns (1)-(3), but not in columns (4)-(6)? The answer can be found in the different mobility measures we employ. The intra-industry measure of mobility used in (4)-(6) is the right measure to the extent that the boundary of the cluster corresponds to SIC industry classifications. If, however, the boundaries of the cluster are not identical to the definition of the SIC industries, the measure in column (1)(3) that counts all job changes for employees initially in SIC 35 and 36, might give a more accurate picture of mobility rates. To see this consider what would happen if all jobs in SIC 35 and 36 are in the IT cluster, but that the cluster also bleeds over into other related industries. For concreteness, imagine that the rates of job hopping in Silicon Valley's and Los Angeles' IT clusters were identical, but 100\% of the employees in San Jose's cluster are in SIC 35 and 36 while in Los Angeles only 50\% of the employers in the IT cluster located in SIC 35 and 36. 
Perhaps the remaining 50\% are located in industries that make instruments used in computers and are therefore classified in SIC 38. Using the measure of mobility in columns (1)-(3) (that counts all mobility in jobs that originate in SIC 35 and 36) we would find that job hopping rates are the same in Los Angeles and Silicon Valley, but using the alternative measure (that accounts only job changes within SIC 35 and 36) the measured rate of job change would be higher in Silicon Valley than LA. There is some reason to believe that the boundaries of IT clusters do bleed into other industries and that this varies systematically by city. ${ }^{19}$ For this reason we interpret the absence of a California effect in columns (4)-(6) with some caution.

Columns (7) and (8) compare the "California" effect on mobility to the "Massachusetts" effect for each of our measures of employer to employer changes. ${ }^{20}$ Massachusetts is interesting because it has the second largest IT cluster after Silicon Valley as well as a very different set of legal rules governing non-compete agreements. In both equations we find a large and statistically significant coefficient on California. We also observe that the coefficient on Massachusetts is smaller than that on California, and that the difference is large in column (7) and small in column (8). In both columns, however, the Massachusetts coefficient is imprecisely measured and one cannot reject the hypothesis that it is zero at conventional significance levels. Unfortunately this imprecision in measurement also means that we cannot reject the hypothesis that the coefficient on California is the same as the coefficient on Massachusetts. ${ }^{21}$ Our in Silicon Valley and San Francisco are highly concentrated in firms that belong in SIC 35 and 36, while the LA/Orange County/San Diego clusters tend to bleed into other industries -

20 especially instrumentation. Our sample is confined to respondents in MSA's defined by Porter as having an information technology cluster. Thus all the respondents for which Massachusetts is equal to one are in MSA 1120 .

21 A $\chi^{2}$ test of the hypothesis that California $=$ Massachusetts in column (7) yields: $\chi^{2}(1)=0.50$ Prob $>\chi^{2}=0.4799$. The similar test for equation (8) yields $\chi^{2}(1)=0.32 \operatorname{Prob}>\chi^{2}=$ 
conservative conclusion is that if a Massachusetts effect exists at all, we cannot be sure that it is different than the California effect. $^{22}$

The results in Table 1 are based on a very broad definition of the computer industry, employees working in establishments that fall into SIC industries 35 and 36. In Table 2, we redo the analysis using a narrower definition. ${ }^{23}$ The results are qualitatively and quantitatively close to those in Table 1. We conclude from this that our findings are not likely to be an artifact of the way we define the computer industry.

Our model of innovation in industrial clusters suggests that hyper-mobility ought not to be a general feature of Silicon Valley or California labor markets. Indeed, if we found evidence of hyper-mobility outside of computers, we might worry that the effects we are attributing to the industrial organization of IT clusters may be due to other, unobserved and unexplored, aspects of these labor markets. In Table 3, we examine mobility patterns for employees not employed in the computer industry in month $t$. We restrict the sample to employees not employed in SIC 35

\subsection{9}

22 Colorado is similar to California in that its state law prohibits non-compete agreements. There are, however, a number of exemptions to this law. For our purposes the most important one is that non-compete's are allowed if they are intended to protect trade secrets. Inserting a dummy variable for Denver into our Table 1 regressions one finds that working in Denver's computer industry increases the probability of job change by 2 percentage points but the estimate is quite imprecise $(\mathrm{z}=1.42)$. It is hard to know if this imprecision is due to the importance of the loophole in the Colorado law or to the small number of observations in Denver, the only MSA in Colorado with an IT cluster. In other unpublished results we re-estimated equation (7) using a complete set of state dummies with California as the omitted state. We find that 11 out of 15 dummies had negatively signed coefficients, a few significantly so, and none had significantly positively signed coefficients. Although many of the individual coefficients were not statistically significant, the entire set of dummies was highly significant. Specifically our narrow definition includes employees in two three-digit census industries: computers and related equipment (Census 322); and electrical machinery, equipment, and supplies, not elsewhere classified (Census 342). Census 322 includes: electronic computers (SIC 3571); computer storage devices (SIC 3572); computer terminals (SIC 3575); and computer peripheral equipment, not elsewhere classified (SIC 3577). Census 342 is a residual category from which most non-computing electrical devices have been excluded. 
or SIC 36 in month $t$. Our dependent variable is equal to 1 if an employee changed employers before the interview in month $t+1$. Comparing the average monthly job change rates conditional on being employed in the computer industry (0.0195) with the average conditional on not being employed in the computer industry (0.0244), it appears that employer to employer movements are more common outside SIC 35 and 36

In column 1 of Table 3, the coefficient on Silicon Valley is small (about $1 / 10^{\text {th }}$ of the mean mobility rate of the population) and we cannot reject the hypothesis that the true effect is zero. Column 2 introduces a California dummy variable into the equation. The coefficient on California is also small, but negative and statistically significant while the Silicon Valley coefficient is positive and significant. The mobility differential for being in Silicon Valley is the sum of these coefficients or 0.001 . This differential is both small and not statistically different from zero $\left(\chi^{2}(1)=0.46\right)$. Similarly when we disaggregate the California effect by introducing dummy variables for the California MSA's with IT clusters (see column 4), we find no evidence that outside the computer industry job changes are more likely within California. Indeed rates of job-hopping appear to be lower in Los Angeles and San Diego than elsewhere in the nation. Taken together, the results in Columns 2 through 4 suggest that the high relative mobility rates in Silicon Valley and California do not hold outside of the computer industry.

We conclude our empirical analysis by considering an alternative explanation of our results. It is possible that mobility rates are higher in the computer industry in Silicon Valley because the high density of computer related employment creates a thick market for similarly skilled college educated men that makes it easy to find a good outside match. If this argument is correct, then looking outside of computers, one should find that a high density of information technology jobs or jobs for college educated men in their own industry ought also to be 
associated with high rates of job turnover. To assess this we introduce two measures of job density into the job change regressions. The first measure, Location Quotient IT, is a measure of the density of employment in the IT cluster in a respondent's MSA. ${ }^{24}$ The second measure, Location Quotient Own Industry, estimates the density of employment in a respondent's industry and MSA relative to the national average. ${ }^{25}$ Introducing these variables into a job change equation yields positive coefficients that are very imprecisely measured considering the size of the sample. Thus we cannot reject the null hypotheses that the effects of Location Quotient IT or Location Quotient Own Industry on mobility are zero. We also cannot reject the hypothesis that these coefficients are jointly zero. ${ }^{26}$ On this basis it does not appear that our results can be explained simply by the thickness of the local market for college educated employees in their own industry or in IT industries.

\section{Conclusion}

This paper uses new data to compare the inter-firm mobility of college educated male employees in Silicon Valley's computer industry to similarly educated employees working in the computer clusters in other cities. The hyper mobility we document for Silicon Valley's computer cluster is consistent with Saxenian's account of agglomeration economies there: frequent job-hopping facilitates the rapid reallocation of resources towards firms with the best innovations. Our finding of a "California" effect on mobility lends support to Gilson's

This variable is constructed by dividing the fraction of MSA employment in it's IT cluster by the national average of the fraction of IT employment in the year 2000. See Cluster Mapping Project (2003), for details.

25 This variable is constructed from our sample of college educated men. For each individual, we calculate the fraction of employment in their two digit census industry in their MSA pooling across the years 1994-2001. We then divide this by the average of all MSA's in our sample. Thus when Location Quotient Own Industry = 1, the respondent's MSA has the same fraction of employment in an industry as does the average MSA. $\chi^{2}(2)=2.89$. We also find that these density measures have no influence on job changes if we insert them into the Table 1 equations that focus only on employees in the computer industry. 
hypothesis that the unenforceability of non compete agreements under California state law enhances mobility and agglomeration economies in IT clusters. Our final finding, that heightened mobility is feature of California's computer industry but not of other California industries, is consistent with our model of modular innovation and with claims that external economies of scale are particularly important for the innovation process in the computer industry.

This interpretation of our results must be qualified by the limitations of our data. We observe only the movement of employees between firms and the correlation of these mobility rates with industry and location. Thus, we cannot rule out the hypothesis that rapid employee mobility may be the result of some unobserved features of computer firms in California rather than the agglomeration economy we posit. In addition, we do not observe employment contracts and therefore have no direct evidence that the "California" effect on mobility is due to the absence of enforceable non-compete agreements. As a result we cannot rule out the role that other factors (such as local culture) may play in sustaining high rates of employee turnover.

Finally, our analysis suggests that agglomeration economies observed in Silicon Valley's IT cluster ought not to be a general economic phenomenon. Rather they should arise in settings, like computers, where the gains from new innovations are both large and uncertain. It would be useful to search for other industries and industrial clusters where this condition might hold to see if these locations are also characterized by enhanced inter-firm mobility. 


\section{References}

1.) Acemoglu, Daron (1997) "Training and Innovation in an Imperfect Labour Market" The Review of Economic Studies, 64:3 p. 445-464.

2.) Acemoglu, Daron. (1996) "A Microfoundation for Social Increasing Returns in Human Capital Accumulation" Quarterly Journal of Economics. 111:3. p. 779-804,

3.) Acemoglu, Daron and Angrist, Joshua.(2000) "How Large Are Human-Capital Externalities? Evidence from Compulsory Schooling Laws." NBER Macroeconomics Annual 15: 1, p9-59.

4.) Acemoglu, D. and J.S. Pischke (1999): "Beyond Becker: Training in Imperfect Labor Markets," The Economic Journal, 109 (February), F112-F142.

5.) Agrawal, A. K., I. M. Cockburn and J. McHale (2003): "Gone Bot Not Forgotten: Labor Flows, Knowledge Spillovers, and Enduring Social Capital," National Bureau of Economic Research (Working Paper 9950), September.

6.) Almeida, Paul and Kogut, Bruce., (1999) "Localization of Knowledge and the Mobility of Engineers in Regional Networks" Management Science. 45:7. p. 905-917.

7.) Angel, David P., (1989) "The Labor Market for Engineers in the U.S. Semiconductor Industry" Economic Geography. 65:2. p.99-112.

8.) Aoki, Masahiko, (2001) Toward a Comparative Institutional Analysis. The MIT Press : Cambridge, Massachusetts and London, England.

9.) Baldwin, Carliss Y. and Clark, Kim B., (1997) "Managing in an Age of Modularity" Harvard Business Review. p.84-93.

10.) Baldwin, Carliss Y. and Clark, Kim B., (2000) Design Rules: The Power of Modularity. MIT Press : Cambridge, Mass. and London, England.

11.) Cluster Mapping Project (2003), Institute for Strategy and Competitiveness, Harvard Business School

12.) Fallick, Bruce and Fleischman, Charles A., (2004) "Employer to Employer Flows in the U.S. Labor Market: The Complete Picture of Gross Worker Flows" Finance and Economics Discussion Series 2004-34, Federal Reserve Board, June 2004.

13.) Gilson, Ronald, (1999) "The Legal Infrastructure of High Technology Industrial Districts: Silicon Valley, Route 128, and Covenants Not to Compete." New York University Law Review. 74:. p.575.

14.) Moretti, Enrico (2004) "Estimating the Social Return to Higher Education: Evidence from Longitudinal and Repeated Cross-Sectional Data" Journal of Econometrics. 121. p.175-212.

15.) Moretti, E. (2004b): "Workers' Education, Spillovers and Productivity: Evidence from PlantLevel Production Functions," American Economic Review, 94: 3, 656-671.

16.) Moen, Jarle, (2000) "Is Mobility of Technical Personnel A Source of R\&D Spillovers?" National Bureau of Economic Research. No.7834. August 2000.

17.) Porter, Michael E., (2003) "The Economic Performance of Regions" Regional Science. 37.:6\&7. p.549-578.

18.) Porter, Michael E., (1998) "Clusters and The New Economics of Competition" Harvard Business Review. 76:6.

19.) Rosenthal, Stuart S. and Strange, William C., (2003) "Evidence on the Nature and Sources of Agglomeration Economies" Working Paper Prepared for the Handbook of Urban and Regional Economics, vol. 4. February 9, 2003.

20.) Rotemberg, J. and G. Saloner (2000): "Competition and Human Capital Accumulation: A Theory of Interregional Specialization and Trade," Regional Science and Urban Economics, 30(4), 373.

21.) Saxenian, Annalee, (1994) Regional Advantage: Culture and Competition in Silicon Valley and Route 128. Harvard University Press : Cambridge, Massachusetts and London England.

22.) Saxenian, Annalee, (1996) "Inside-Out: Regional Networks and Industrial Adaptation in 
Silicon Valley and Route 128" Cityscape. 2:2. p.41-60.

23.) Saxenian, Annalee, (2000) "The Origins and Dynamics of Production Networks in Silicon Valley" Understanding Silicon Valley: The Anatomy of an Entrepreneurial Region. edited by Martin Kenney. Stanford University Press: Stanford. 
Table 1

Determinants of Month-to-Month Job Changes: Conditional on Being in The Computer Industry Broadly Defined (SIC 35 and 36 )

(3)

(4)

(5)

(6)

(7)

(8)

\begin{tabular}{|c|c|c|c|c|c|c|c|}
\hline & & & $\begin{array}{c}\text { Change } \\
\text { Jobs }\end{array}$ & $\begin{array}{c}\text { Change } \\
\text { Jobs }\end{array}$ & $\begin{array}{c}\text { Change } \\
\text { Jobs }\end{array}$ & & $\begin{array}{c}\text { Change } \\
\text { Jobs }\end{array}$ \\
\hline Change & Change & Change & Within & Within & Within & Change & Within \\
\hline Jobs & Jobs & Jobs & Industry & Industry & Industry & Jobs & Industry \\
\hline [0.0195] & [0.0195] & [0.0195] & [0.009] & [0.009] & [0.009] & [0.0195] & [0.009] \\
\hline 0.008 & 0.000 & 0.011 & 0.008 & 0.006 & 0.009 & & \\
\hline$(2.02)^{\star}$ & $(0.100)$ & $(2.54)^{\star}$ & $(3.27)^{\star \star}$ & (1.750) & $(3.37)^{\star \star}$ & & \\
\hline & 0.011 & & & 0.002 & & 0.012 & 0.006 \\
\hline & $(2.66)^{\star \star}$ & & & $(0.880)$ & & $(3.43)^{\star \star}$ & $(2.98)^{\star \star}$ \\
\hline & & 0.015 & & & 0.004 & & \\
\hline & & $(2.41)^{\star}$ & & & $(1.050)$ & & \\
\hline & & 0.002 & & & 0.000 & & \\
\hline & & $(0.280)$ & & & $(0.090)$ & & \\
\hline & & 0.015 & & & 0.002 & & \\
\hline & & $(1.860)$ & & & $(0.420)$ & & \\
\hline & & & & & & 0.008 & 0.005 \\
\hline & & & & & & (1.48) & (1.24) \\
\hline 0.00 & 0.00 & 0.003 & 0.01 & 0.005 & 0.005 & 0.002 & 0.005 \\
\hline$(0.37)$ & $(0.37)$ & $(0.36)$ & $(1.24)$ & (1.23) & $(1.24)$ & $(0.35)$ & (1.23) \\
\hline-0.003 & -0.001 & -0.001 & -0.002 & -0.001 & -0.001 & -0.001 & -0.002 \\
\hline$(0.74)$ & $(0.34)$ & $(0.39)$ & $(0.85)$ & $(0.70)$ & $(0.71)$ & $(0.37)$ & $(0.82)$ \\
\hline-0.003 & -0.002 & -0.002 & 0.000 & 0 & 0 & -0.002 & 0 \\
\hline$(0.82)$ & $(0.71)$ & $(0.73)$ & (0.19) & $(0.17)$ & $(0.19)$ & $(0.64)$ & $(0.12)$ \\
\hline 0.001 & 0.00 & 0.00 & $(0.00)$ & -0.001 & -0.001 & 0.001 & -0.001 \\
\hline$(0.30)$ & $(0.47)$ & $(0.44)$ & $(0.56)$ & $(0.51)$ & $(0.53)$ & $(0.36)$ & $(0.42)$ \\
\hline yes & yes & yes & yes & yes & yes & yes & yes \\
\hline yes & yes & yes & yes & yes & yes & yes & yes \\
\hline yes & yes & yes & yes & yes & yes & yes & yes \\
\hline 8966 & 8966 & 8966 & 8966 & 8966 & 8966 & 8966 & 8966 \\
\hline 2972 & 2972 & 2972 & 2972 & 2972 & 2972 & 2972 & 2972 \\
\hline
\end{tabular}

Variable [mean]

Silicon Valley [0.166]

California [.302]

Los Angeles [0.069]

Orange County $[0.030]$

San Diego [0.037]

Massachusetts [0.089]

Full-Time [0.961]

US Citizen [0.748]

Married [.753]

Post College Schooling [.332]

Year Fixed Effects 1994 - 2001

Month fixed effects

Age Dummy Variables

Observations

Number of Individuals

Absolute value of robust $z$-statistics in parentheses (with standard errors adjusted for clustering within individual). ${ }^{*}$ significant at $5 \%$; ** significant at $1 \%$

The dependent variable is equal to 1 if respondent changed jobs between two consecutive months. Up to 6 potential transitions are observed for each individual. These estimates are for job changes from month $t$ to $t+1$ conditional on being employed in the computer industry (SIC 35 and 36 ) in month t. Thus, from column 1 , we see that we observe 2972 individuals over 8,966 month to month observations. $1.95 \%$ of these potential job changes resulted in actual job changes.

The coefficients in the table are derivatives, i.e. they reflect the impact of the variable on the probability of observing a job change between two consecutive months. Thus, in column 1, residing in Silicon Valley increases the probability of job change by $0.8 \%$, roughly forty percent above the base rate of job change for the sample.

In columns (2) and (5) chi square tests indicated that Silicon Valley and California were jointly significant at better than the $1 \%$ level. In columns (3) and (6) chi square tests indicate that Silicon Valley, Los Angeles, and Orange County were jointly significant at the $5 \%$ level. One cannot reject the hypothesis that these coefficients are jointly equal in magnitude either.

The variable Silicon Valley includes the cities of San Jose, San Francisco and Oakland California. Age dummies are: $<25 ;<35,<45,<55,<65$ years old 
Table 2

Determinants of Month To Month Job Transitions Conditional on Being Employed in the Computer Industry Narrowly Defined (Census 322 and 342 )

\begin{tabular}{|c|c|c|c|c|c|c|c|c|}
\hline Variable [mean] & $\begin{array}{c}\text { Change } \\
\text { Jobs } \\
{[0.0196]}\end{array}$ & $\begin{array}{c}\text { Change } \\
\text { Jobs } \\
{[[0.0196]}\end{array}$ & $\begin{array}{c}\text { Change } \\
\text { Jobs } \\
{[0.0196]}\end{array}$ & $\begin{array}{c}(4) \\
\text { Change } \\
\text { Jobs } \\
\text { Within } \\
\text { Industry } \\
\text { [0.0083] }\end{array}$ & $\begin{array}{c}(5) \\
\text { Change } \\
\text { Jobs } \\
\text { Within } \\
\text { Industry } \\
\text { [0.0083] }\end{array}$ & $\begin{array}{c}(6) \\
\text { Change } \\
\text { Jobs } \\
\text { Within } \\
\text { Industry } \\
\text { [0.0083] }\end{array}$ & $\begin{array}{c}\text { Change } \\
\text { Jobs } \\
{[0.0196]}\end{array}$ & $\begin{array}{c}(8) \\
\text { Change } \\
\text { Jobs } \\
\text { Within } \\
\text { Industry } \\
{[0.0083]}\end{array}$ \\
\hline Silicon Valley [0.224] & $\begin{array}{c}0.014 \\
(3.14)^{\star \star}\end{array}$ & $\begin{array}{l}0.002 \\
(0.32)\end{array}$ & $\begin{array}{c}0.019 \\
(3.79)^{\star \star}\end{array}$ & $\begin{array}{c}0.008 \\
(3.55)^{\star \star}\end{array}$ & $\begin{array}{l}0.006 \\
(1.79)\end{array}$ & $\begin{array}{c}0.009 \\
(3.67)^{\star \star}\end{array}$ & & \\
\hline California [0.350] & & $\begin{array}{c}0.015 \\
(3.04)^{\star \star}\end{array}$ & & & $\begin{array}{l}0.002 \\
(0.91)\end{array}$ & & $\begin{array}{c}0.017 \\
(4.29)^{\star \star}\end{array}$ & $\begin{array}{c}0.008 \\
(3.58)^{\star \star}\end{array}$ \\
\hline Los Angeles [0.063] & & & $\begin{array}{c}0.019 \\
(2.39)^{\star}\end{array}$ & & & $\begin{array}{l}0.002 \\
(0.64)\end{array}$ & & \\
\hline Orange County [0.028] & & & $\begin{array}{l}0.011 \\
(1.03)\end{array}$ & & & $\begin{array}{l}0.006 \\
(1.12)\end{array}$ & & \\
\hline San Diego [0.034] & & & $\begin{array}{c}0.023 \\
(2.17)^{\star}\end{array}$ & & & $\begin{array}{c}0 \\
(0.01)\end{array}$ & & \\
\hline Massachusetts [0.093] & & & & & & & $\begin{array}{l}0.006 \\
(0.84)\end{array}$ & $\begin{array}{l}0.004 \\
(1.06)\end{array}$ \\
\hline Full-Time [0.965] & $\begin{array}{l}0.005 \\
(0.60)\end{array}$ & $\begin{array}{l}0.004 \\
(0.50)\end{array}$ & $\begin{array}{l}0.004 \\
(0.50)\end{array}$ & $\begin{array}{l}0.002 \\
(0.43)\end{array}$ & $\begin{array}{l}0.002 \\
(0.42)\end{array}$ & $\begin{array}{l}0.002 \\
(0.42)\end{array}$ & $\begin{array}{l}0.004 \\
(0.49)\end{array}$ & $\begin{array}{l}0.003 \\
(0.55)\end{array}$ \\
\hline US Citizen [0.732] & $\begin{array}{l}0.002 \\
(0.59)\end{array}$ & $\begin{array}{l}0.004 \\
(1.00)\end{array}$ & $\begin{array}{l}0.004 \\
(0.98)\end{array}$ & $\begin{array}{l}0.000 \\
(0.25)\end{array}$ & $\begin{array}{l}0.000 \\
(0.12)\end{array}$ & $\begin{array}{c}0 \\
(0.09)\end{array}$ & $\begin{array}{l}0.004 \\
(0.99)\end{array}$ & $\begin{array}{l}0.000 \\
(0.25)\end{array}$ \\
\hline Married [0.749] & $\begin{array}{l}-0.005 \\
(1.38)\end{array}$ & $\begin{array}{c}-0.004 \\
(1.19)\end{array}$ & $\begin{array}{l}-0.005 \\
(1.21)\end{array}$ & $\begin{array}{l}0.001 \\
(0.47)\end{array}$ & $\begin{array}{l}0.001 \\
(0.51)\end{array}$ & $\begin{array}{l}0.001 \\
(0.55)\end{array}$ & $\begin{array}{l}-0.004 \\
(1.14)\end{array}$ & $\begin{array}{l}0.001 \\
(0.70)\end{array}$ \\
\hline Post College Schooling [0.348] & $\begin{array}{l}-0.005 \\
(1.26)\end{array}$ & $\begin{array}{l}-0.004 \\
(1.02)\end{array}$ & $\begin{array}{l}-0.004 \\
(1.03)\end{array}$ & $\begin{array}{l}-0.003 \\
(1.81)\end{array}$ & $\begin{array}{l}-0.003 \\
(1.75)\end{array}$ & $\begin{array}{l}-0.003 \\
(1.73)\end{array}$ & $\begin{array}{l}-0.004 \\
(1.07)\end{array}$ & $\begin{array}{l}-0.004 \\
(1.77)\end{array}$ \\
\hline Year Fixed Effects 1994 - 2001 & yes & yes & yes & yes & yes & yes & yes & yes \\
\hline Month fixed effects & yes & yes & yes & yes & yes & yes & yes & yes \\
\hline Age Dummy Variables & yes & yes & yes & yes & yes & yes & yes & yes \\
\hline Observations & 5773 & 5773 & 5773 & 5773 & 5773 & 5773 & 5773 & 5773 \\
\hline Number of Individuals & 1961 & 1961 & 1961 & 1961 & 1961 & 1961 & 1961 & 1961 \\
\hline
\end{tabular}

Absolute value of robust z-statistics in parentheses (with standard errors adjusted for clustering within individual). * significant at $5 \%$; ** significant at $1 \%$

The dependent variable is equal to 1 if the respondent changed jobs between two consecutive months. Up to 6 potential transitions are observed for each

individual. These estimates are for job changes from month $t$ to $t+1$ conditional on being employed in the computer industry narrowly defined (Census 322 or 342 )

in month t. Thus, from column 1, we see that we observe 1961 individuals over 5773 month to month observations. $1.96 \%$ of these potential job changes resulted in actual job changes.

The coefficients in the table are derivatives, i.e. they reflect the impact of the variable on the probability of observing a job change between two consecutive months

Thus, in column 1, residing in Silicon Valley increases the probability of job change by $1.4 \%$, roughly $70 \%$ above the base rate of job change for the sample.

Age Dummy Variables: $<25 ;<35,<45,<55,<65$. In columns (2) and (5) chi square tests indicated that Silicon Valley and California were jointly significant at better than the $1 \%$ level. In columns (3) and (6) chi square tests indicate that Silicon Valley, Los Angeles, and Orange County were jointly significant at the $1 \%$ level. One cannot reject the hypothesis that these coefficients are jointly equal in magnitude either. 
Table 3

The Determinants of Month-to-Month Job Changes Conditional on not Being Employed in the Computer Industry (i.e. not being in SIC 35 or 36)

\begin{tabular}{|c|c|c|c|c|c|}
\hline Variable [mean] & $\begin{array}{c}(1) \\
\text { Change } \\
\text { Jobs } \\
{[0.0244]}\end{array}$ & $\begin{array}{c}(2) \\
\text { Change } \\
\text { Jobs } \\
{[0.0244]}\end{array}$ & $\begin{array}{c}(3) \\
\text { Change } \\
\text { Jobs } \\
{[0.0244]}\end{array}$ & $\begin{array}{c}(4) \\
\text { Change } \\
\text { Jobs } \\
{[0.0244]}\end{array}$ & $\begin{array}{c}(5) \\
\text { Change } \\
\text { Jobs } \\
{[0.0244]}\end{array}$ \\
\hline Silicon Valley [0.067 ] & $\begin{array}{l}0.002 \\
(1.05)\end{array}$ & $\begin{array}{l}0.004 \\
(2.16)^{\star}\end{array}$ & $\begin{array}{l}0.001 \\
(0.69)\end{array}$ & & $\begin{array}{l}0.004 \\
(1.79)\end{array}$ \\
\hline California [0.238] & & $\begin{array}{l}-0.003 \\
(2.51)^{\star}\end{array}$ & & $\begin{array}{r}-0.002 \\
(1.81)\end{array}$ & $\begin{array}{l}-0.003 \\
(2.65)\end{array}$ \\
\hline Los Angeles [0.126] & & & $\begin{array}{l}-0.003 \\
(2.00)^{\star}\end{array}$ & & \\
\hline Orange County [0.023] & & & $\begin{array}{l}-0.001 \\
(0.37)\end{array}$ & & \\
\hline San Diego [0.022] & & & $\begin{array}{l}-0.006 \\
(2.16)^{\star}\end{array}$ & & \\
\hline $\begin{array}{l}\text { Location Quotient IT Sector } \\
\text { [1.91 ] }\end{array}$ & & & & & $\begin{array}{c}-0.00002 \\
(0.06)\end{array}$ \\
\hline $\begin{array}{l}\text { Location Quotient Own Industry } \\
\text { [0.984] }\end{array}$ & & & & & $\begin{array}{l}0.013 \\
(1.53)\end{array}$ \\
\hline Massachusetts [.083] & & & & $\begin{array}{l}-0.001 \\
(0.78)\end{array}$ & \\
\hline Full-Time [ 0.871] & $\begin{array}{c}-0.016 \\
(12.42)^{\star \star}\end{array}$ & $\begin{array}{c}-0.016 \\
(12.49)^{\star \star}\end{array}$ & $\begin{array}{c}-0.016 \\
(12.49)^{\star \star}\end{array}$ & $\begin{array}{c}-0.016 \\
(12.48)^{\star \star}\end{array}$ & $\begin{array}{c}-0.016 \\
(12.46)^{\star \star}\end{array}$ \\
\hline US Citizen [0.842] & $\begin{array}{l}0.001 \\
(0.62)\end{array}$ & $\begin{array}{l}0.000 \\
(0.15)\end{array}$ & $\begin{array}{l}0.000 \\
(0.22)\end{array}$ & $\begin{array}{l}0.000 \\
(0.19)\end{array}$ & $\begin{array}{l}0.000 \\
(0.10)\end{array}$ \\
\hline Married [0.683] & $\begin{array}{l}-0.003 \\
(3.27)^{\star \star}\end{array}$ & $\begin{array}{l}-0.003 \\
(3.39)^{\star \star}\end{array}$ & $\begin{array}{l}-0.003 \\
(3.38)^{\star \star}\end{array}$ & $\begin{array}{l}-0.003 \\
(3.43)^{\star *}\end{array}$ & $\begin{array}{l}-0.003 \\
(3.42)^{\star \star}\end{array}$ \\
\hline Post College Schooling [0.375] & $\begin{array}{l}-0.001 \\
(1.51)\end{array}$ & $\begin{array}{l}-0.001 \\
(1.63)\end{array}$ & $\begin{array}{l}-0.001 \\
(1.61)\end{array}$ & $\begin{array}{l}-0.001 \\
(1.55)\end{array}$ & $\begin{array}{l}-0.001 \\
(1.70)\end{array}$ \\
\hline Year Fixed Effects & yes & yes & yes & yes & yes \\
\hline Month fixed effects & yes & yes & yes & yes & yes \\
\hline Age Dummy Variables & yes & yes & yes & yes & yes \\
\hline Observations & 147183 & 147183 & 147183 & 147183 & 147183 \\
\hline $\begin{array}{l}\text { Number of Individuals } \\
\text { Observed/Potential iob changes }\end{array}$ & 42232 & 42232 & 42232 & 42232 & 42232 \\
\hline Observed/Potential job changes & 0.024412 & 0.024412 & 0.024412 & 0.0232 & 0.0232 \\
\hline
\end{tabular}

Absolute value of robust z-statistics in parentheses (with standard errors adjusted for clustering within individual).

* significant at $5 \%$; ** significant at $1 \%$

The dependent variable is equal to 1 if respondent changed jobs between two consecutive months. Up to 6 potential transitions are observed for each individual. These estimates are for job changes from month $t$ to $t+1$ conditional on not being employed in the computer industry (SIC 35 and 36) in month t. Thus, from column 1, we see that we observe 42232 individuals with 147,183 month to month observations. $2.4 \%$ of these potential job changes resulted in actual job changes. The coefficients in the table are derivatives, i.e. they reflect the impact of the variable on the probability of observing a job change between two consecutive months. Thus, in column 1, residing in Silicon Valley increases the probability of job change by $0.2 \%$, less than $1 / 10$ th of the sample mean. 
Table 3

The Determinants of Month-to-Month Job Changes Conditional on not Being Employed in the Computer Industry (i.e. not being in SIC 35 or 36)

Age Dummy Variables: $<25 ;<35,<45,<55,<65$.

In column (2), the mobility differential from living in Silicon Valley is the sum of the coefficients on Silicon Valley and California. One cannot reject the hypothesis that the sum of these coefficients is $0\left(\chi^{2}=0.46\right)$.

Location Quotient IT is a ratio measure of the concentration of a cluster in a particular location relative to the national average. Thus Location Quotient IT > 1 indicates a higher than average concentration in that location in the year 2000 (see Cluster Mapping Project Institute for Strategy and Competitiveness for details).

Location Quotient Own Industry is an analogous variable constructed using our sample of college educated men. We first calculate the fraction of college educated men in an MSA who are in each two-digit census industry and then divide this by the average value for the entire sample. Thus Location Quotient Own Industry $>1$ indicates an MSA which has a higher fraction of college educated employees in a census industry than the average across all MSA's. 